\title{
ADATOK JOHANN JACOB KHÜN „ÉRSEKI UDVARI FESTŐ” MÜKÖDÉSÉHEZ, LIPPAY GYÖRGY POZSONYI NYARALÓKASTÉLYÁNAK ÚJONNAN ELŐKERÜLT KELETI LÁTKÉPE (1663) KAPCSÁN ${ }^{1}$
}

\begin{abstract}
A Lippay György esztergomi érsek (1600-1666) pozsonyi nyári rezidenciáját részleteiben megörökítő, 1663-ban megjelent rézmetszetsorozat mindeddig lappangó darabja a nyaralókastély keleti összképét mutatja (1. kép). ${ }^{2}$ Az esztergomi Főszékesegyházi Könyvtárban jelzet nélkül őrzött, ismeretlen provenienciájú metszetlapon a képmező alatt, középen kétsoros kurzív felirat olvasható: Facies extrinseca redificy totius Palatÿ, et Horti Principis ArchiEpiscopi Strigoniensis Posonÿ exstructi, simul cum forinseco prospectu. (Az esztergomi érsek pozsonyi kastélyának és kertjének külső össznézete, kívülről tekintve.) ${ }^{3}$ Jobbra, lent a rajzoló jelzése tűnik fel: J Jacob Khün delin:. A képmező széle mentén körbevágott lap mérete a sorozat többi ránk maradt darabjáéhoz hasonló: $170 \times 260 \mathrm{~mm}$ (papír), $169 \times 258$ mm (kép), $150 \times 258$ mm (felső képmező). A papíron középen a Hortus Italicust ábrázoló ismert lapon $^{4}$ szereplővel azonos bécsi vízjel látható. ${ }^{5}$
\end{abstract}

Az együttes keleti összképét bemutató lap feltehetően a sorozat legelső darabja volt - ahogy a korabeli épület-, illetve kertlátképszériák esetében a külső távlati nézet általában; erre utalhat, hogy egyedül e lap feliratában szerepel Pozsony mint helyszín, valamint az esztergomi érsek mint az épület és kert tulajdonosa. Bél Mátyás az újonnan előkerült keleti és a Facies totius horti főcímet viselő nyugati látkép ${ }^{6}$ egymást kiegészítő tanulságait összegezte a sorozatot tárgyaló leírásának kezdetén, az előbbi alapján mutatva be a szőlőhegyek lábánál elterülő kert kellemes fekvését, a kelet és nyugat felé egyaránt szabad kilátást, az egyemeletes nyaralókastélyt, valamint a véghomlokzatukkal kelet felé néző udvari szárnyakat és az azok által közrezárt udvart, amely a Boldogságos Szűz szobrával és a Lippayak nemesi címerével ékes külső kapujával „a királyi útra” (a térség középtengelyében futó, a 18-19. században „Fürstenallee"-nak nevezett útra) nyílik. ${ }^{7}$

A kompozíció a Matthäus Merian és utódai által megjelentetett Topographia Germaniae (1642-1654) alacsonyabb horizontú, tágas síkvidéki előtér mögött húzódó városfalakat és amögül kiemelkedő városi épületeket mutató látképeinek típusát követi. ${ }^{8}$ A kastély dísztelen keleti homlokzata és erődszerüen zárt kerítésfala előtt elterülő, a korban kisebb lovassági gyakorlatoknak és felvonulásoknak helyet adó, láthatóan kaszálóként használt nyílt térség középső sávjában katonák staffázsalakjai vonulnak; az épület hátterében a várostól nyugatra emelkedő szőlőhegyek és dombok tünnek fel, topográfiai hűségre törekvő ábrázolásban. Az épületek kissé vázlatos, összességében azonban hitelesnek tekinthető megjelenítése a Notitia leírásában is szereplő részletek bemutatásával pontosítja az együttes korabeli állapotáról alkotható képet, és - kiegészítve az ismert nyugati (kerti) össznézet alapján levonható következtetéseket - néhány fontos új információval is szolgál. Ábrázol például egy eddig ismeretlen részletet: a déli udvari szárny homloksíkja elé ugró, balusztráddal koronázott, árkádos toldalékot. A kémények helyzetének, illetve a keleti homlokzat emeleti nyílásainak (a tengelyek számát illetôen legalábbis vélhetően hiteles) ábrázolásával, továbbá a melléképületek és a majorság épületeinek arányhelyes - a kastély tömbjét az utóbbiak rovására monumentalizáló nyugati látképnél pontosabb - megjelenítésével az újonnan előkerült keleti össznézet fontos forrásul szolgálhat az együttes topográfiájának megismeréséhez, valamint az emeleti terek funkcióját és az 1761-1765 között Franz Anton Hillebrandt irányításával végzett átépítés mibenlétét feltáró kutatásokhoz. ${ }^{9}$ A látképen a kert részletei 


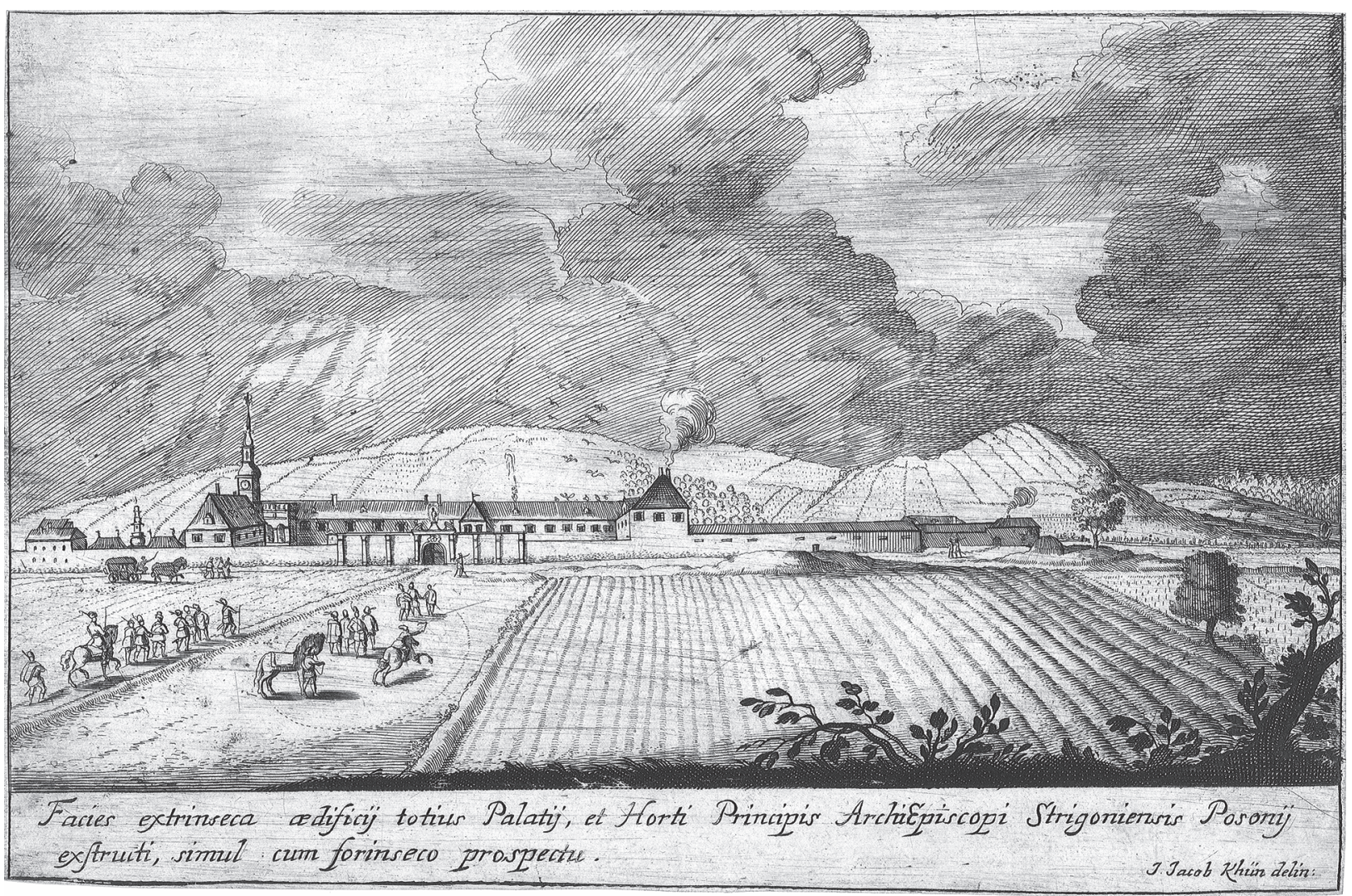

A pozsonyi érseki nyaralókastély látképe kelet felöl. Mauritius Lang rézmetszete Johann Jacob Khün rajza után, Pozsony 1663. Esztergom, Főszékesegyházi Könyvtár, Grafikai Gyüjtemény, C/IV. fiók, jelzet nélkül

közül csupán egyetlen apró, jelzésszerúen ábrázolt motívum: a kert főtengelyében álló grottát koronázó, szamárállkapcsot emelő Sámson-figura és az onnan felszökő vízsugár látható az épület hátterében.

A metszet kivitelezője a sorozat címlapját jelző (s feltehetően a teljes széria metszését végző) Mauritius Lang lehetett. Neve nem szerepel a lapon, ismét feltűnik azonban a kompozíciók előrajzait készítő festő: Johann Jacob Khün (Hans Jacob Khien) jelzése - akárcsak a széria dedikációs lapjának végleges változatán, ${ }^{10}$ újabb bizonyságot adva a teljes sorozat esetében feltételezhető rajzolói közreműködéséről.

Khün későbbi, részletesebben dokumentált kismartoni tevékenységétől (1667-1672) eltérően Lippay érsek udvari festőjeként való szerepléséről mindeddig csupán egyetlen forrás tudósított: A Sankt Stephan plébániájának anyakönyvi bejegyzése szerint Bécsben 1668 júliusában mint "gewesener erzbischöfflicher Kammermaler in Pressburg" kötött házasságot bizonyos Anna Barbara Permannal. ${ }^{11}$ E dokumentum alapján Garas Klára Khün részvételét feltételezte a pozsonyi érseki nyári rezidencia festészeti dekorációjában,, ${ }^{12}$ és elhelyezte abban a festők és szobrászok négynél több generációját magában foglaló, igen kiterjedt, besztercebányai eredetű famíliában, amelynek
Besztercebányán, Pozsonyban, Nagyszombatban és Bécsben dolgozó tagjait elsőként kísérelte meg öszszekapcsolni ${ }^{13}$ a lőcsei származású Johannes (Hans) Khuen besztercebányai aranyművestől (megh. $1584)^{14}$ és a berzevicei "Zmeskál-epitáfiumot" (1600) készítő idősebb Jacob Khientől (megh. 1619 után) ${ }^{15}$ a Bécsben felnőtt és ott működő, Itáliát megjárt és számos fennmaradt művet hátrahagyó Johann Ferdinand Khien (1656-1723) táj- és csataképfestőig. ${ }^{16}$ A különböző családtagok neve számos változatban és írásmóddal szerepel a forrásokban, ${ }^{17}$ rokoni kapcsolataik terén pedig ma is sok a bizonytalanság annak ellenére, hogy Radoslav Ragač utóbb publikálta az idősebb Jacob Khienre és fiaira: Johannra és Jacobra vonatkozó levéltári dokumentumokat. ${ }^{18}$

A Khien família Bécsben letelepült tagjai és a Lippay érsek számára dolgozó Johann Jacob Khün kapcsolatát, valamint utóbbi és a besztercebányai család között fennálló rokonságot általánosságban igazolni látszik a fent említett anyakönyvi bejegyzés adata, miszerint Khün házasságkötésének tanúja a besztercebányai születésű, 1655-ben Bécsben házasodott és haláláig ott élő festő („,bürgerlicher Maler”): Johann Christoph Khien (1625-1688), a csataképfestő Johann Ferdinand apja volt. ${ }^{19}$ Johann Christoph 
Khien a források alapján feltehetően az idősebb Jacob Khien unokája: annak 1580 körül született, szintén festőként múködő idősebb fia: Johann gyermeke volt ${ }^{20}$ és hasonló rokoni kapcsolatban állhatott a „Zmeskál-epitáfium” alkotójával Johann Jacob Khün is. ${ }^{21}$ (Az idősebb Jacob Khien fiatalabb fia, aki szintén a Jacob nevet kapta, 1619-ben Sziléziába távozott tanulmányi céllal mint ,, artis pictoreae studiosus". $)^{22}$

Johann Christoph Khien bécsi festő és a pozsonyi prímási udvarban működő Johann Jacob Khün a család ugyanazon generációjához tartozhatott; életútjának évszámai alapján utóbbi is 1625 körül születhetett. Khün festői müködésének legkorábbi forrása 1653. november 26-i kifizetésének igazolása: ekkor 84 forintot kapott Pálffy (IV.) Miklós (16191679) pénztárából egy címer festéséért gróf Pálffy (IV.) Pál nádor castrum dolorisához, majd ezt újabb 12 forintos juttatás követte 1654 . október 5 -én. ${ }^{23}$ Halálának időpontja ismeretlen: 1672-ben még feltűnik a kismartoni plébánia anyakönyvében, ${ }^{24}$ az 1680-as években talán őt említik Nagyszombatban a források ${ }^{25}$ és vélhetően ő szerepel a bécsi Sankt Stephan plébániájának anyakönyvében is azonos nevű fia keresztelője kapcsán 1682. április 11-én. ${ }^{26}$

A család ugyanezen generációjához tartozott még két testvér, akik pozsonyi illetőségük alapján következtethetően a fentieknél közelebbi kapcsolatban állhattak az érseki nyaralókastély és kert látképeit készítő festővel. Egyikük „a másik” Johann Christoph Khien, a szobrász, 1695-ben a nagyszombati Szentháromság-emlék tervezője és vezető kivitelezője. ${ }^{27}$ Egyetlen további munkáját ismerjük: Kollonich Lipót érsek megrendelésére a pozsonyi érsekkert „bejáratánál”, azaz a nyaralókastély kerti homlokzata előtt, a fötengelyben futó sétány indulásánál elhelyezett két piramidális obeliszk köveinek faragásáért kap fizetséget 1697 április 4-én, ${ }^{28}$ majd még ugyanabban az évben távozik az élők sorából. ${ }^{29}$ Sokat foglalkoztatott pozsonyi szobrászként említi működésének legkorábbi dokumentuma: Petheő István jezsuita Nagyszombatban, 1683. szeptember 20-án kelt, Gribóczi Mihályhoz, a kassai kollégium rektorához írt levele, amely részletesen ismerteti a vörösmárványból és tatai mészkőből készítendő nagyszombati szobormű kétféle (a győri és a bécsi, illetve a pozsonyi emlékhez hasonlított) tervezetét: a pozsonyi szobrász és kőfaragó („,sculptor et lapicida Posoniensis") által bemutatott két nagyméretú rajzot. ${ }^{30} \mathrm{~A}$ levélíró leírásai lezárásaként a tervek készítőjének (és a választott megoldás majdani vezető kivitelezőjének) személyéről is szól: „A szobrász igen kiváló művész: Kien úrnak, a pozsonyi medikusnak fivére, katolikus, akit pozsonyi építészeti és kőfaragómunkáknál alkalmaznak, és aki maga is igen kiválóan dolgozik." ${ }^{31}$
A pozsonyi orvos, Johann Christoph Khien fivére feltehetően nem más, mint a besztercebányai születésü Ferdinand Khien, aki néhány évig Johann Weber (1612-1684) eperjesi városi orvos, Wesselényi Ferenc nádor udvari gyógyszerésze, a mecénási tevékenységéről is nevezetes későbbi főbíró ${ }^{32}$ fiainak nevelöje volt, s Eperjesen, Weber gyógyszertárában töltötte gyakorlóéveit. ${ }^{33}$ Ennek emléke Weszprémi István által is idézett szerzeménye: Weber Janus Bifrons seu Speculum Physico Politicumához (Lőcse 1662) írt elógiuma, amelyben Khien tanárának művészet iránti vonzalmára és városszépítési törekvéseire utal. ${ }^{34}$ Gyakorlóéveit követően Ferdinand Khien 1663. január 5-én kezdte meg tanulmányait a wittenbergi egyetemen mint eperjesi orvosjelölt; 1667-ben doktorált, majd maga is városi orvos lett Eperjesen. Neve 1682 és 1686 között három alkalommal jelenik meg a bécsi Sankt Stephan és a Schottenkirche anyakönyveiben: a festő Johann Christoph Khien házassági tanújaként 1682. október 5-én mint „,aulae medicus" szerepel..$^{35}$ Későbbi életútjáról és 1683-ban jelzett pozsonyi kötődésének mibenlétéről nem szólnak az eddig feltárt források. Sem Ferdinand, sem testvére, a szobrász Johann Christoph Khien születési idejét nem ismerjük; kevés életrajzi adatuk alapján az 1625-1640 körüli évekre, illetve Ferdinand esetében leginkább 1640 körülre tehető.

Johann Jacob Khün Lippay érsek környezetében való munkálkodásának alig néhány további dokumentuma került elő. A jelenlétéről tudósító rövid említések mellett egyetlen forrás szól bővebben személyéről: az épp Eperjesen tartózkodó Polycarpus Procopius Bonannushoz, Lippay érsek orvosához („,aulae aepiscopalis familiaris et medicus"), tudományos és művészeti kérdésekben egyaránt jártas bizalmasához ${ }^{36}$ írt, Pozsonyban, 1659. június 19én kelt levele, amelyet mint „Hannß Jacob Khünn Maller" szignált (1. melléklet). ${ }^{37}$

Khün ismerőseként szólítja meg Bonannust, és régebbi keletü kapcsolatukra és annak momentumaira következtethetünk a levél hangvételéből, a mondatok tartalmi elemeire csak utaló megfogalmazásokból is. E bizalmas nexus lehetséges előzményeiből a források csupán arról tudósítanak, hogy Khün korábban is dolgozott Pozsonyban Lippay érsek megrendelésére: Ulrich Steidler (1620-1661), Lippay érsek pozsonyi gyógyszertárának apotékáriusa ${ }^{38}$ Pozsonyban, 1659. február 17-én kelt, Bonannushoz szóló (Selmecbányára címzett) levelében beszámol arról, hogy „Jacob festôt” az érsek „kegyesen és megelégedéssel” elbocsátotta, s hogy ugyanezen "Jacob" egy másik festőt is hoz majd a prímásnak. ${ }^{39}$ Ugyanerről értesíti Bonannust az épp Pozsonyban, Lippay érseknél tartózkodó Daniel Neuberger (1621-1680) császári udvari 
szobrász és viaszmintázó is február 25 -én. ${ }^{40}$ E híradások egyben Khün érseki udvari festőként való müködésének legkorábbi adatai.

Khün Bonannusnak írt levelében örömét fejezi ki afelett, hogy „az úr találkozott fivérével, Ferdinanddal" - nyilván Eperjesen -, és hogy fivére „,az úrral" marad "tanulmányai végett", majd utal a megfelelő tudományos grádussal („,promotion”) és összeköttetésekkel rendelkező, Lippay érsekkel („,a mi legkegyelmesebb hercegünkkel") is közeli kapcsolatban álló „doctor" közvetítő szerepére. ${ }^{41}$ Kéri, hogy Bonannus intézze el nevében „az úrral” ("mit seinem herrn”), hogy „fordítsák haszonra” testvére tanulmányai miatt hátrahagyott (felmondott) egyévi kvártélyát, az úr döntése szerint, majd, immár saját ügyében, hogy állapodjon meg helyette az érsekkel („,mit seinem herrn Prinzen”) a nála töltött időre kellő ruházatot és más szükséges dolgokat illetően, ígérve, hogy idő előtti menesztése esetén mindent megfizet. ${ }^{42}$ Khün teljes körű felhatalmazást ad a „doktornak” az ügyben, s hogy e fáradságáért ismét(!) ne maradjon szolgálattal adósa, levelével két lapot küld Bonannus elkészült rézmetszeteiből („2. Exemplar von seinen gestochnen Khupffer”), jelezve, hogy küldött volna több exemplárt is, de a postával nem lehet, majd arra kéri a doktort, írja meg, ha további teendő akad.

A levél Khün családi kapcsolataira vonatkozóan fontos adatot tartalmaz: a festő testvére, Ferdinand minden bizonnyal a medikusnak készülő Ferdinand Khien, akit Petheő István fent idézett levelében a szobrász Johann Christoph Khien fivéreként említ. ${ }^{43}$ Ferdinand Khien besztercebányai származása dokumentált, ${ }^{44}$ feltehetően mind a három testvér ott született tehát: Johann Jacob Khün, a Pozsonyban működő érseki udvari festő, Johann Christoph Khien pozsonyi szobrász és kőfaragó, valamint Ferdinand Khien, az orvos, apjuk pedig talán a már említett ifjabb Jacob Khien, a „Zmeskálepitáfiumot" készítő idősebb Jacob kisebbik fia, aki sziléziai útjáról 1621-ben tért vissza Besztercebányára, további sorsa azonban nem ismert. ${ }^{45}$

Az eperjesi „úr", akit Khün levelében testvére, Ferdinand tanulmányai kapcsán emleget, minden bizonnyal nem más, mint Johann Weber, akinek apotékájában az ifjú gyógyszerésztanonc éppen ekkor: a levél keletkezése körüli időben (az 1662 előtti években) kezdhette meg gyakorlóéveit, nem mellékesen Lippay prímás medikusa, Bonannus segítő közbenjárására.

Khün sajnos nem szól bővebben a levélben említett metszetekről, így minden értelmezési kísérlet csak bizonytalan alapokon nyugvó feltételezéseket eredményezhet. A szóban forgó „exemplárok” vélhetően nem azonosak az érseki nyaralókastélyt és kertjét megörökítő széria lapjaival, amelyek rajzi előkészítésére feltehetően legkorábban a levél keletkezése körüli időben vagy inkább még később: 16601663 között (a „szivárványos" kutak elkészülte után) került sor. ${ }^{46}$ Khün szavai alapján küldeménye sokkal inkább a "doktornak” szóló, személyes szolgálat tárgya lehetett. Valószínűnek tünik, hogy Bonannus nagyszabású, legendás művéről: a több mint 200 rézmetszetes táblával tervezett, Magyarország geográfiai és mineralógiai értékeinek reprezentatív leírását adó, De admirandis Hungariae rebus címen elhíresült opusról van szó, amelynek ásvány- és kőzetgyüjtési munkáit és kiadásra való előkészítését (legkésőbb 1652-től) Lippay prímás és gróf Nádasdy Ferenc országbíró (1623-1671) közösen támogatta. ${ }^{47}$ A szerző váratlan halála $(1664)^{48}$ miatt végül kiadatlanul maradt és mára elveszett mű emléke máig töretlenül él a természettudományokkal és azok történetével foglalkozó irodalomban. Elsőként Philipp Jacob Sachs von Löwenheim (Lewenhaimb, 1627-1672) boroszlói orvos, az Academia Naturae Curiosorum titkára ad hírt a készülő kiadványról 1661-ben, még Bonannus életében, ${ }^{49}$ majd annak halála után, 1670-ben ugyanő tudósít ismét a müről az Academia illusztrált folyóirata, a Miscellanea curiosa hasábjain, immár részletesebben bemutatva a kéziratban maradt munkát és annak sajnálatos sorsát, az illusztrációs táblák számáról is megemlékezve („plusquam ducentis Tabulis æneis"). ${ }^{50}$ A műről való első szakmai híradások forrása az eperjesi orvosok köre: Sachs mindkét alkalommal Martinus Heinricus Franckenstein eperjesi városi orvos levelére hivatkozik, és a következő, 1671-ben, úgyszintén a Miscellanea curiosában megjelent rövid ismertetés szerzője is eperjesi illetőségü: ezúttal Johann Paterson Hain városi orvos. ${ }^{51}$

Az 1657 körüli időtől császári és királyi főbányaorvosként címzett Bonannus ${ }^{52}$ levelezésében állandó témaként jelenik meg a tervezett mü, az ásványés kőzetgyűjtés, valamint a kövek csiszoltatásának ügye, az opus kiadásának technikai részleteiről azonban viszonylag kevés szó esik a levelekben. ${ }^{53}$ Különösen ritkán fordul elő a munka illusztrációira való utalás; ezekre az ügyet patronáló Nádasdy Ferenc Bonannushoz szóló, fennmaradt leveleinek egyetlen sora vonatkozik csupán: Seibersdorfban, 1660. február 29-én kelt levelében Nádasdy sietteti az ábrák befejezését. ${ }^{54} \mathrm{Az}$ illusztrációk finanszírozására vonatkozóan hallgatnak a források, a kész mú nyomtatására azonban Nádasdy utal fent említett levelében: az előkészületek, úgy tűnik, saját nyomdájában zajlottak. ${ }^{55}$

Khün levelében foglalt rövid utalása azt sejteti, hogy részt vett a mü illusztrációinak készítésében, amit a szerző környezetében való állandó jelenléte is valószínűsít. Tájékozott lehetett Bonannus ásvány- 
és kőzetgyüjtési tevékenységét illetően, és tudott az ezzel kapcsolatos részletekről is; legalábbis ezt sugallják Daniel Neuberger sorai, akivel - többek között a (garam)szentkereszti prímási uradalom területén felfedezett, Nádasdy „és társai” által bérelt jáspisbányából származó kövek Neubergernél végzett csiszoltatása és művészi faragása okán Bonannus 1658-1660 között élénk levelezést folytatott: ${ }^{56}$ Neuberger Bécsben, 1660. február 8-án kelt levelében arról panaszkodik Bonannusnak, hogy a „doktor úrtól” nem érkeznek hozzá kövek (feltehetően a jáspisbányából), és megjegyzi, hogy már Khünnél, a festőnél is érdeklődött erről, aki éppen Bécsben (nála) járt. ${ }^{57}$ Úgy tűnik, a jáspisbánya anyagából is készültek ábrák: Neuberger egy bizonyos festővel együtt 1660. március 4-én azt javasolja, hogy a nála lévő legnagyobb kőről készüljön durva vázlat, amelyet szétküldenének, illetve összehasonlítási alap gyanánt használhatnának a többi lelet értékeléséhez, tehát annak eldöntéséhez, mely darabokat érdemes végül gondosan lerajzoltatni. ${ }^{58} \mathrm{~A}$ bécsi kőről, úgy tűnik, a Neuberger által említett festő készítette volna a szóban forgó vázlatrajzot, akit Neuberger nem nevez meg, azonban levele elején nem kisebb személyről, mint Frans Luycx császári udvari festőről (1604-1668) szól („H Liücx alß Kaisl: Chammer mahler" $),{ }^{59}$ más festőt pedig a továbbiakban nem említ, így talán elképzelhető, hogy ugyanő a segítség felajánlója is. E munkamódszerrel, mint Neuberger mondja, nagy hasznára lehetnének az ügynek, hogy valamennyi ábra elkészüljön, és Nádasdy („,der $\mathrm{H}^{\mathrm{r}}$ : Kraff”) minél előbb kinyomtathassa a lapokat (,Exemplaria") ${ }^{60}$ aki ekkor, mint a fentiekből kiderül, már igencsak sürgette az illusztrációk befejezését Bonannusnál.

Bár a Bonannus ásványgyưjteményének javát bemutató rézmetszetes táblák legtöbbje nyilván a korszak jellegzetes, ám a művészettörténet szokványos tárgykörén kívül eső grafikai müfaja, a természettudományos illusztráció körébe tartozott, ${ }^{61} \mathrm{a}$ mü keletkezéstörténetének ránk maradt dokumentumai helyenként a pozsonyi érsekkert berendezése vonatkozásában is jelentős összefüggésekről, kapcsolatokról tájékoztatnak. Bonannus az egyházi és világi főurak által foglalkoztatott, széles körü műveltséggel rendelkező udvari orvosok típusának jellegzetes képviselőjeként ${ }^{62}$ a kor társadalmának legkülönbözőbb tagjaival tartott fenn gyümölcsöző és sokszor igen sokrétü, több esetben az érsekkert látványosságainak kialakítása szempontjából is fontos ismeretséget. ${ }^{63} \mathrm{~A}$ forrásokban csak csekély nyomokat hagyó személyes nexusok dokumentumai, úgy tűnik, a pozsonyi érsekkert esetében különös jelentőséggel bírnak, ahogy valamelyest a nyári rezidenciát bemutató metszetsorozat rajzait készítő
Johann Jacob Khün kapcsolatait és udvari múködésének hátterét is megvilágítják.

A sorozat megjelenését követő évben Khün már gróf Esterházy Pál (1635-1713), a későbbi nádor, herceg udvari festőjeként dolgozott: ${ }^{64}$ Bécsben, 1664. december 23-án kelt szerződése szerint két éven át köteles volt minden negyedévben egy „képet írni" megbízójának (vagyis összesen nyolc képet kellett szállítania), továbbá ezen idő alatt meg kellett tanítania egy inast a képírás mesterségére megrendelőjének „szándéka és intentuma szerint”, és tanítványának teljes ellátást kellett biztosítania, 200 forint fizetésért. ${ }^{65}$ Az Esterházy Pál levéltári iratanyagában fennmaradt, feltehetően 1669 körül készült, „Az bécsi képek Laistroma” címet viselő festményjegyzék Khün egy művét is tartalmazza: egy félalakos Mária-képet („No. 34. Ein frauen bilt mit halben leib von Jacob Kien"), e müve azonban, úgy tünik, elveszett vagy lappang. ${ }^{66}$

Khün kismartoni munkáiról 1667. és 1669. évi szerződése tájékoztat. ${ }^{67} 1667$. április 22-én nyolc helyiség kifestését vállalta négyszáz forintért. ${ }^{68}$ E munka befejeztével, 1669. január 12-én kötött szerződése nyolc további helyiség: egy „a középső szinten lévő, vörösmárvány padlóburkolattal ellátott szoba”, egy „amellett elhelyezkedő kis sarokszoba”, „a kápolnánál lévő szoba”, „,a grófnő asszony audienciás szobája és annak előszobái", a „régi négyszögletü toronynál lévő egyik szoba”, valamint az utóbbi felett, a felső szinten „két sarokszoba" kifestésének elkészítésére kötelezte, újabb négyszáz forint és természetbeni juttatások ellenében. ${ }^{69}$ Míg az 1667-ben kelt szerződés nem részletezi a kifestésre szánt nyolc helyiség elhelyezkedését, illetve funkcióját, az 1669. évi irat szövege alapján már megkísérelhető a „Hanß Jacob Khien pozsonyi festö" által dekorált helyiségek azonosítása. ${ }^{70} \mathrm{~A}$ felsorolás első három tétele az északnyugati torony három egymásba nyíló helyiségére vonatkozhat, amelyek csoportja magában foglalja a közvetlenül a nagyteremből megközelíthető (s vélhetően azzal megegyező padlóburkolattal ellátott) kisebb termet, valamint egy sarokszobát és egy a kápolna felé eső helyiséget. ${ }^{71}$ A következő tétel a kápolnától délre lévő helyiségcsoport: a család nőtagjainak lakosztályát képező ún. "Frauen Zimmer” lehet. Itt a "grófnő asszony audienciás szobájához" (azaz feltehetően a délnyugati torony nyugati oldalán elhelyezkedő, osztott szobához) északról egy másik helyiség csatlakozott, amely a szerződésben mint "anthe stube" szerepel..$^{72} \mathrm{~A}$ ",régi torony" elnevezés talán az északkeleti „öreg óratoronyra" vonatkozik; a szerződésben ennek egyik szobájáról, illetve két, felette elhelyezkedő helyiségről lehet szó. ${ }^{73}$ A tételek tehát, úgy tünik, a kastély emeletének nyugati 
oldalán lévő, jellemzően lakófunkciójú (nem reprezentatív) helyiségekre vonatkoznak, a korábbi szerződés pedig feltehetően a keleti oldalon sorakozó lakószobák kifestését célozta. E tizenhat helyiség mára elpusztult 17. századi kifestésének részleteiről nincsenek adataink. ${ }^{74}$

Esterházy Pál 1664-tôl 1671-ig állandóan szerződésben állt udvari festőjével („vnßer Maller"), e sorozatos megbízások kezdetének körülményeit és idejét azonban nem ismerjük. 1664. évi szerződése feladatának jellege alapján feltételezhetően nem minden előzmény nélkül köttetett, Khün Esterházy Pál számára végzett korábbi munkáiról azonban hallgatnak az eddig előkerült források. Csupán annyit tudunk, hogy a gróf egy bizonyos „pozsonyi képírót” foglalkoztatott már 1660-ban, a győri ferences templom egyik (akkor majdani temetkezési helyeként meghatározott) kápolnájába szánt oltár elkészíttetéséhez. Kovách Ambrus (Ambrosius), a győri (korábban a nagyszombati) konvent gvardiánja Győrött, 1660. március 24én kelt levelében arról érdeklődik a grófnál, hogy fenntartja-e „az temető helyt”a náluk lévő kápolnában annak ellenére, hogy Nagyszombatban is van "temető helyek", majd arról tájékoztatja, hogy a „pozsonyi képíró” a „meg nevezett kápolnában náluk leendő oltár végett” várja tőle „az oltarnak mintáját" és a kivitelezéshez szükséges utasításokat. ${ }^{75}$ Minden bizonnyal a győri konvent 18 . századi protokollumában említett oltáradományról van szó: Esterházy Pál kétszáz forintot adott a tűzvész után újjáépített és 1659-ben elkészült ferences templom „első kápolnájának" mára elveszett oltárára. ${ }^{76}$

A pozsonyi érseki nyári rezidenciáról készült metszetszéria ránk maradt lapjaitól eltekintve Lippay érsek pozsonyi udvari festőjének múvei közül egyelőre egyet sem sikerült azonosítani. E minőségében kötött szerződéseinek tárgyát nem ismerjük, és tevékenységének eddig előkerült adatai nem hozhatók összefüggésbe a pozsonyi nyaralókastély és a kert festészeti dekorációjának a források alapján megismerhető részleteivel. Bár Esterházy Pál szolgálatában való működésének dokumentumai valamelyest többet árulnak el feladatairól, a festő-famíliából származó Khün kiterjedt munkássága, dokumentált családi kapcsolatai és életútja ellenére egyelőre csupán a pozsonyi metszetsorozat előrajzai révén emelkedik ki a korszak név szerint ismert, de fennmaradt művekkel nem jellemezhető városi festőinek sorából. ${ }^{77}$

\section{FÜGGELÉK}

Johann Jacob Khün levele Polycarpus Procopius Bonannusnak Eperjesre

Pozsony, 1659. június 19.

Prímási Levéltár, Esztergom, Archivum Saeculare, Acta Radicalia, Classis X, Nr. 196, 35. csomó, 69-71.

[69]

Eol vester vnd Hochgelehrter Herr Brueder Bonano Deß Herrn seiet Meine wüllige die[n]sten neben einen freundtlichen Grueß Jederzeit beuor. Hab vernommen, daß der herr hat meinen Bruedern Ferdinandt Angetroffen. erfreuet mich Zuer hőren, vnd mit dem herrn wegen seiner Studiæ vort $\mathrm{Zu}$ sezen welches ist mür gar Lieb. Mit Gueter promotion, würdt der Herr doctor selber solche mitl woll wüssen Alß durch vnsern Gnedigsten fürsten, In dem anderen Bitt ich den herrn doctorn der herr doctor wolle müt seinem Herrn an Statt Meiner Qvartieren wegen Nachlassung eines Jahrs, daß er Ime dasselbige in seiner Studiae Khündte $\mathrm{Zu}$ einen Nuzhen machen nach seinem Vornemmen würs der herr doctor auch selbst für Guett erachten Thuet, auch den herrn doctorn bitten tuche, er woll seinen herrn Prinzen wegen Chleidungen oder sunsten Nothturfftigkheiten welche am Im seiet angewendtet worden. mit Ime abkhommen. ich dasselbige verspriche Zubezallen wan er in mintern: Jahren freÿsprehen wülle, so bitt ich den herr doctor: der herr doctor wolle solches an Statt Meiner mit seinen herrn Prinzen Disponiern alß wan ich selbsten darbeÿ wehre, ich ÿber geb dem herrn doctor völlig vollmacht. dise Mühe an den herrn Doctorn wüder mït Meinen diensten Zuunschulden, [70] In den ÿberigen ÿberschikh ich dem herrn 2. Exemplar von seinen gestochnen Khupffer. wär Im weiter Zutain ist khann khan mïr der herr doctor wüder schr[e]iben, ich hette dem herrn doctorn Gern Mer Exemplar geschikht, aber sie seiet gar Böß fortzuschikhen sonderlich auf der post, der herr doctor seÿ von mür vnd den Meingen Gar schön gegriest Gott beuolhen. datum Prespurg den. 19. Junÿ 1659.

P.S Ich khan dem hern doctorn weiter nihts schreiben alß daß der Landtag G[e]wiß vortgehe.

Deß herrn doctorn dienstwilligen

Ich Hannß Jacob Khünn Maller

\section{[71: címzés a külzeten:]}

An den Eol vnd gestrengen auch hochgelehrten herrn Policarpo Procopio Bonnano der Medicin: Doctor Meinen Insonderen Hochgeehrten herrn $\mathrm{Zu}$ handen Epperies. 


\section{JEGYZETEK}

1 Jelen dolgozat az OTKA K 105005 számú pályázata támogatásával, valamint az Isabel és Alfred Bader Müvészettörténeti Kutatási Támogatás segítségével készült Lippay György prímás pozsonyi nyári rezidenciája és kertje 17-18. századi történetének újrafeldolgozását célzó PhD-disszertációm (ELTE BTK Művészettörténet-tudományi Doktori Iskola) előkészítéseként.

2 A pozsonyi érsekkertről és a metszetsorozatról a korábbi irodalom összefoglalásával l. Ecsedy 2013. A továbbiakban az ott ismertetett forrásokra legnagyobbrészt nem hivatkozom, csak az ezektől eltérő forrásokat jelölöm.

3 FK, Grafikai Gyüjtemény, C/IV. fiók. Az ábrázolás tárgya (a felirat alapján meghatározva, a lapnak az 1663-as szériával való összefüggése nélkül) ceruzával a lap gyüjteményi pecséttel ellátott hátoldalán feltüntetve szerepel: „Az esztergomi érsek pozsonyi palotájának és kertjének teljes látképe." - Ezúton mondok köszönetet Mechler Katalinnak és az esztergomi Főszékesegyházi Könyvtár munkatársainak, akik kutatásomat lehetővé tették és segítették.

4 Magyar Nemzeti Múzeum, Történelmi Képcsarnok, ltsz.: 74.2. Első közlése: Stirling János: Lippay György pozsonyi kertjének egy ismeretlen ábrázolása 1663-ból. A Kertészeti Egyetem Közleményei XLVIII. 1984, Budapest 1986, 329-337: 329, 335-337, 5. ábra; adatait, bibliográfiáját 1. Ecsedy 2013, Függelék, I. 5.

5 Egy Bécsben 1683. december 4-én kelt nyugta papírja például a metszetlapéval azonos vízjelet visel (díszített kettős körben koronás büszt elölnézetben, fent középen mitra, mögötte keresztben kulcs és keresztes bot kettős kontúrral, a kör mellett balra $\mathrm{H}$, jobbra $\mathrm{K}$ betújel); 1 . PL AS, II. Acta Radicalia, Classis X, Nr. 196, 62. csomó, 207208. A széria címlapjának korábbi levonatán látható vízjel ettől eltérő, kettős hatágú csillag, díszítőmotívumokkal kísért kettős körbe foglalva. (MTA Könyvtár, Kézirattár és Régi Könyvek Gyưjteménye, ltsz.: RM III. 947. Első közlése: Rapaics 1938, 666, 1. kép; adatait, bibliográfiáját 1 . Ecsedy 2013, Függelék, I. 1a, a vízjelre vonatkozóan hibás megállapítással).

6 MTA Könyvtár, Kézirattár és Régi Könyvek Gyűjteménye, ltsz.: RM III. 947 Első közlése: Rapaics 1938, 666, XLII. tábla; adatait, bibliográfiáját 1. Ecsedy 2013, Függelék, I. 2.

7 Matthiae Belii Notitia Hungariae Novae Geographico Historica. Partis Primae Cis-Danubianae, Tomus primus. Viennae 1735, 640: „Situs, extra modum hilaris, horto obtigerat: quippe, ad collium vitiferorum radices, positionis erectae, \& prospectus, in orientem atque meridiem, liberrimi. Antica pars, praetorium habet, longo aedificil ordine, praestructum, \& duabus discretum contignationibus. quod, sicuti frontem horto obuerit; ita, duabus vtrinque alis, in aream retorquetur, qua viam regiam prospicit. Itaque, gemina ditur porta, exteriore altera, simulacro B. M. VIRGINIS, \& gentilitio Lippaiorum insigni, conspicua; altera interiore, quae praetorium subit, \& recta, in ambulacrum, quod est totius horti laxissimum, deducit." A részlet fordításai: Pigler Andor: A pozsonyi prímási kert. Napkelet VI. 1925/6-10, 29-34: 31-32; Wellmann Imre szerk.: Bél Mátyás: Magyarország népének élete 1730 táján. (Történetírók tára sorozat. Budapest 1984, 266.) - A Bél Mátyás leírásának idején még fennálló (jelen időben említett) kapu átalakítására csak 1737-38ban került sor; erről 1. Prokopp Gyula: Levéltári adatok Georg Raphael Donner pozsonyi éveihez. Ars Hungarica VI. 1978/2, 329-339: 334, 16. jegyzet. A nyaralókastély keleti homlokzata előtt elterülő térségről (a későbbi Esterházytérről) 1. Ortvay Tivadar: Pozsony város utcái és terei. A város története utca- és térnevekben. Pozsony 1905. Reprint (facsimile): Pozsonyi könyvtár 6. Budapest 1991, 50-52.

8 A müről és a Merian-műhely további topografikus kiadványairól 1. elsősorban: Lucas Heinrich Wüthrich: Das druckgraphische Werk von Matthaeus Merian d. Ae. Bd. 4: Die großen Buchpublikationen II. Die Topographien; Vorläufer: Topographie von Deutschland, Frankreich, Rom, Italien, Windhaag; Nachträge zu den Handzeichnungen und zum Druckgraphischen Werk, Bände 1 bis 3. Hamburg 1996, a Merian-Topographiák városlátképei közül vö. például: uo., Nr. SWA 23 (Brackenheim, 1643), MTK 68 (Uerdingen, 1646), WFA 43, 44 (Paderborn, 1647), WFA 62 (Bochum, 1647), WFA 67 (Dülmen, 1647), WFA 69 (Haltern am See, 1647), BSL 26 (Artzen, 1652).

$9 \mathrm{Az}$ épületegyüttes topográfiáját és építéstörténetét is tisztázni igyekvő tanulmány előkészületben. A nyaralókastély épületéről és 18. századi átépítéséről összefoglalóan 1. elsősorban: Klára Garas: Das Reisejournal des Architekten Johann Michael Küchel aus dem Jahre 1737. Die Reise in Ungarn. Acta Historiae Artium 22. 1976, 133154: 146, 154; Kelényi György: Franz Anton Hillebrandt (1719-1797). (Müvészettörténeti Füzetek 10.) Budapest 1976, 18; G. Györffy Katalin: Kultúra és életforma a XVIII. századi Magyarországon. (Idegen utazók megfigyelései.) (Müvészettörténeti Füzetek 20.) Budapest, 1991, 83-84, 643-650. jegyzet.

10 MTA Könyvtár, Kézirattár és Régi Könyvek Gyüjteménye, ltsz.: Képek 2-rét 46. Közölve: Ecsedy 2013, 172173, 2. kép, Függelék, I. 1b.

11 Hajdecki 1908, 6856. sz.

12 Garas 1953, 59; Garas 2000, 355, 32. jegyzet, egyúttal jelezve, hogy Giorgio Stockamer müncheni festő, továbbá Sigismondo di Gasparo Benzenhauser "da Possognia” szintén Lippay érsek udvarában dolgozott mint festo”; forrása: Flavia Nacamulli: Michael Fabris Ongaro. Arte Veneta XXXIX. 1985, 87-100: 88-89, 100. Stockhammerrő1 1. továbbá: Petr Fidler: Beiträge zu einem Künstler- und Kunsthandwerkerlexikon des Donaugebietes. IV. Teil. Ars 1997/1-3, 221-252: 241 (1678-ban Pozsony városa 17 forintot fizet neki Lipót császár portréjáért).

13 Garas 1953, 105, 135-136; Garas 2000, különösen 342-343, 4. jegyzet.

14 Az 1551-től dokumentált Johannes Khuen besztercebányai aranyművesről, aki Kemény Lajos felvetése szerint az idősebb Jacob Khien apja lehetett (Kemény Lajos: Khien Jakab. Müvészet X. 1911, 46-47; átveszi Garas 1953, 136; Barbara Balážová: Mešt'ania banských miest a „Kunst” v ich domácnostiach. In: Rusina 2009, 199-209: 202: 30. jegyzet, 204; vö.: Ragač 2005, 248) és müvéről, Radvánszky György kelyhéről (1576; Magyar Nemzeti Múzeum, Budapest, ltsz. 1933.14) újabban (a korábbi irodalom bibliográfiájával) Mikó - Verő 2008, 323-324: kat. sz. IX-91 (Kiss Erika); Rusina 2009, 914-915: kat. sz. 275 (Zuzana Francová).

15 Az 1598-tól dokumentált idősebb Jacob Khienre vonatkozó első szakirodalmi adatok összefoglalása: Garas 
1953, 136; újabban 1. Ragač 2005, különösen 248-253, 255 (a besztercebányai plébániatemplom számára végzett munkáiról: feltehetően a templom korábbi, Szent Kristófot, valamint Szent Pált és az apostolokat ábrázoló falképeinek felújításáról szóló 1598. évi források ismertetésével); Balážová 2007, 22, 24: 28., 29., 33. jegyzet); Balážová 2009, 50, 52, 53. A berzevicei Mindenszentek r. k. plébániatemplomban Zmeskál Jób által feleségének: az 1600. június 17-én elhunyt Gelethfy Petronellának állított "Zmeskál-epitáfiumról” legújabban összefoglalóan, bibliográfiával 1. Mikó - Verő 2008, 172-173: kat. sZ. V-24 (Mikó Árpád); Rusina 2009, 857-858: kat. sz. 215 (Galavics Géza), 858-860: kat. sz. 216 (Josef Medvecký). A körmöcbányai plébániatemplom 1590-1593 között készült Jézus születése-oltárképét (Národná banka Slovenska - Múzeum mincí a medailí v Kremnici, ltsz. 1678/56, U-1432) Barbara Balážová feltételesen a felesége révén körmöcbányai kötődésü Jacob Khien mühelyéhez kapcsolja; 1. Balážová 2007, különösen 22, a műhely feltételezését alátámasztó forrást idézi uo., 24: 33. jegyzet; Rusina 2009, 838: kat. sz. 201 (Barbara Balážová).

16 Személyének és oeuvre-jének részletes ismertetése: Garas 2000, különösen 341-354. A család további tagjairól részletesen 1 . alább.

17 Garas 2000, 343. A továbbiakban valamennyiük esetében a „Khien” írásmódot használom a prímási udvari festő kivételével, akinek vezetékneve a pozsonyi nyári rezidencia látképein és alább ismertetett saját kezü levelének aláírásában egyaránt „Khün” formában szerepel.

18 Ragač 2005, különösen 250-255.

19 Hajdecki 1908, 6856. sz. - Johann Christoph Khien 1668-tól szerepel az idézett megjelöléssel a bécsi anyakönyvekben; ugyanekkortól lakhelyeként a Khienmarkton (Wien I., a mai Wildpretmarkton) lévő „Michael Rost Haus" tünik fel. 1685-ben még ugyanitt lakott (,,im Martin Heußel Haus"), 1688-ban bekövetkezett halálakor azonban neve mellett „Bürgerl. Maler und Stadthauptmann im jungen Schottenviertel im Dorotheerhof" kommentár szerepel. A személyét érintő bejegyzéseket (1655-1688) 1. Hajdecki 1908, 6856., 6883., 6903., 6916., 6969., 7010., 7739., 8106., 9514., 9514., 9518., 9530., 9669., 10784., 10809., 10814., 10940., 10998., 11125., 11193. sz. Festői működésére vonatkozóan egyetlen bejegyzés tartalmaz adatot: 1657. június 28-án Maria Barbara von Zinzendorf (Khevenhüller von Aichelberg, 1624-1696) komornájának esküvői tanújaként „des herrn von Zinzendorf maler" megjelöléssel szerepel, tehát Albrecht von Zinzendorf (1618-1683) szolgálatában dolgozott. Életrajzi adatait összefoglalja: Garas 2000, 342, 343: 4. jegyzet.

20 A Bécsben működő festő leszármazására vonatkozó feltételezés Garas Klára és Radoslav Ragač adatainak kombinációja: az 1625-ben Besztercebányán született Johann Christoph apja Johann Khien volt (Garas 2000, 343: 4. jegyzet), az idősebb Jacob Khien (a „Zmeskál-epitáfium” alkotója) 1598-ban már apja mellett dolgozó (tehát 1580 körül vagy kevéssel később született), 1611-ben polgárjogot nyert és a forrásokban festőként szereplő idósebb fiát pedig Johann-nak hívták (Ragač 2005, 251-255).

21 Vö. Balážová 2009, 53: 30. jegyzet, Johann Jacob Khün és a festő Johann Christoph személyét és életrajzi adatait felcserélve.

22 Ragač 2005, 253-254. - Ragač feltételezésének, miszerint a Lippay érsek által foglalkoztatott Johann Jacob
Khün az idősebb Jacob Khien fiaként említett Johann Khiennel azonos (Ragač 2005, 254), ellentmondani látszanak az évszámok. Az 1668-ban házasodó Johann Jacob nem születhetett 1580 körül (a kettejük között feltételezhető életkorbeli eltérés éppen egy generációnyi különbségnek felel meg; 1. a 20. jegyzetet), és nem valószínű, hogy a kettős keresztnevében mindkét fivér nevét viselő és használó prímási festő bármelyikükkel azonos lehetne.

23 Petr Fidler: Beiträge zu einem Künstler- und Kunsthandwerkerlexikon des Donaugebietes (Österreich, Slowakei und Ungarn). Exzerpta aus den Archiven in Preßburg und Tyrnau. III. Teil. Ars 1996/1-3, 225-239: 227 (forrása: Slovenský národný archív, Bratislava, Pálffy, A VIII, L 2, F 3, Nr. 1-4, Pálffy Miklós, Pozsonyi uradalom, 17. századi elszámolások, Nr. 88); adatait átveszi: Garas 2000, 343: 4. jegyzet.

24 Csatkai -Frey 1932, XXVIII: 4. jegyzet.

25 Štibrányiová 1987, 88, az azonos nevü, de ismeretlen foglalkozású személyről szóló források megjelölése nélkül.

26 Hajdecki 1908, 9543. sz. (Mint azonos nevü gyermekének apja, „Primus Kien”-ként szerepel. Az anya keresztneve az 1668. évi házassági bejegyzésben is feltűnő Anna Barbara.) Khün bécsi anyakönyvekben való további szereplése nagyon bizonytalan: még két keresztelési bejegyzésben jelenik meg azonos vagy hasonló név (1671-ből és 1688-ból), azonban foglalkozás megjelölése és a személyére utaló egyéb támpontok nélkül; 1 . Hajdecki 1908, 9897., 10524. sz.

27 A Johann Christoph Khien szobrász életére és a nagyszombati Szentháromság-emlék készítésére vonatkozó forrásokat Mária Štibrányiová ismertette: Štibrányiová 1987, 87-88, 91: 34. jegyzet. Egyetlen hiteles múve a Szentháromság-emlék, ennek ellenére Ján Papco az emlék szoboralakjainak figuratípusait és meglehetősen tágan értelmezett stílusjellemzőit alapul véve újabban több, stílus és kvalitás tekintetében teljességgel különböző művet kísérelt meg a nevéhez kötni (sőt, a Štibrányiová szerint vele egy időben Nagyszombatban említett szobrász - talán fia: Johann Georg Khien nevéhez): így a nagyszombati jezsuita templom déli homlokzatának Szent Pál-fülkeszobrát (homokkő), a privigyei Szent Bertalanplébániatemplom egykori oltárának a bajmóci (Bojnice) Múzeumba került faszobrait: Szent Pál, Szent István és Szent László figuráit és egy feszületet, egy ismeretlen származású, kifejezetten provinciális megformálású török-figurát (fa, Západoslovenské múzeum v Trnave / Nyugat-Szlovákiai Múzeum, Nagyszombat), Esterházy Pál és hitvese síremlékfigurái mellett (MNG RMGy, ltsz. 52.759, 52.762); 1. legutóbb: Ján Papco: Rakúsky barok a Slovensko. Nové nálezy, atribúcie. / Österreichisches Barock und die Slowakei. Neue Funde, Attributionen I-II. Slovenské národné múzeum - Múzeum Bojnice. Bojnice 2003, I. 128-139: kat. sz. 57-62. Az Esterházy-síremlékfigurákhoz vö. elsősorban: Galavics Géza szerk.: Barokk müvészet Közép-Európában. Utak és találkozások. / Baroque Art in Central Europe. Crossroads. Budapesti Történeti Múzeum, 1993. június 11. - október 10. Katalógus. Budapest 1993, 412-414: kat. sz. 184, 185 (Galavics Géza).

$28 \mathrm{Az}$ elszámolás két (azonos) példánya: PL AS, X. Számvevőségi Levéltár, 1. Gazdasági számadások: (2.) Nagyszombati uradalom, 1. doboz (609. sz.), Extractus Menstruus [...], mensis Aprilis Ao 1697: „Die. 4. Apr Lapicidae Chien pro Anni praeteriti quadrato lapide, qui 
in horto pro lusu pyramidum exstat, dedi fli 2." A csúcsukon kőgömbbel és lánggal ellátott obeliszkek láthatók Martin Engelbrecht Friedrich Bernhard Werner rajza után, 1735 körül készült, az érsekkert keleti össznézetét adó rézmetszet-látképén (legújabban, a korábbi közlések bibliográfiájával 1. Fatsar Kristóf: Magyarországi barokk kertmüvészet. Budapest 2008, 189-190: 84/1. sz.) Későbbi, Georg Rossbinder kőfaragó által végzett javításaik adatai: PL AS, X. Számvevőségi Levéltár, 1. Gazdasági számadások: (8.) Pozsonyi uradalom, 1708. év, 190. tétel és 1711. év, 116. tétel; 1. az MTA BTK MI Regesztagyüjteményében: A-VIII-3, számozatlan regeszták, készítette: Prokopp Gyula, 1973-1977. Az iratok az obeliszkek helyzetét a Werner metszetén láthatóval azonosan jellemzik.

29 Štibrányiová 1987, 88.

30 MOL E 152 (Acta Jesuitica), Irregestrata, Collegium Cassoviense, 203. doboz, 13. tétel, p. 173-176. - A levél gépelt átirata az MTA BTK MI Regesztagyüjteményében: A-I-16/ 3599-3602. regeszta, készítette: Gyéressy Béla, 1958-1968. (A regesztában hibás évszám: 1638 szerepel.) - A Szentháromság-emlék kivitelezése 1689-ben már zajlott (Štibrányiová 1987, 88).

31 Uo., p. 174: „Sculptor est artifex eximius: Frater Domini Kien medici Posoniensis, Catholicus uteretur in Architectura opera Lapicidae Posoniensis, qui et ipse eximie laborat."

32 Weber János személyéről és mecénási működéséről 1. elsősorban: Bubryák 2003, valamint: Bubryák Orsolya: Weber János és a Wappen der königlichen freyen Stadt Epperies. Irodalomtörténeti Közlemények XCIX. 1995/34, 335-343.

33 Ferdinand Khienről 1. elsősorban: Weszprémi 1781, 173-178; Weszprémi / Kővári (1781) 1968, 384-395; Szinnyei József: Magyar írók élete és munkái, VI. Budapest (1899) 1980, 185-186 (az itt ismertetett biográfiai adatokat tartalmazó művek bibliográfiájával). Műveit: disszertációját, szakmai munkáit, alkalmi szerzeményeit 1 . továbbá: RMK III/1. 2221, 2269, 2307, 2274, 2207, 2409, 2421.

34 RMK II. 992; Weszprémi 1781, 177-178; a vers újraközlése és fordítása: Weszprémi / Kövári (1781) 1968, 392 393; jelentőségéről 1. még: Bubryák 2003, 264.

35 Két alkalommal (1682-ben és 1686-ban) 1. Johann Christoph Khien házassági tanújaként: Hajdecki 1908, 6969., 7010. sz.; Georg Theodor van der Lohr, Gonzaga Eleonóra udvari ékszerésze (Haupt 2007, 2703. sz.) esküvői tanújaként 1682-ben 1. Hajdecki 1908, 7799. sz. Talán fia: „Paul Khin Apotheker” tünik fel 1698. október 18-án a kassai születésü Franciscus Piazol „Stukkatorgesell” esküvői tanújaként; 1. uo., 8530. sz.

36 Bonannus személyéről részletesen 1. Ernyey 1912, 122-128.

37 PL AS, II. Acta Radicalia, Classis X, Nr. 196, 35. csomó, 69-71.

38 A gyógyszertárat Lippay érsek 1654-ben saját használatára rendezte be, majd 1658-ban a pozsonyi jezsuita kollégiumnak ajándékozta. A patika alapításának körülményeiről legújabban 1. Fridrich Perényi: Bývalá jezuitská lekáreň Salvátor v Bratislave. Bratislava: Spisy Mestského Múzea v Bratislave V. 1969, 75-113: 79-84. Ulrich (Udalricus) Steidler 1655-től 1661-ig töltötte be az apotékáriusi tisztséget; 1. Lippay érsekhez szóló, Pozsonyban, 1656. december 28-án kelt levelét, amelyben (a nemrégiben elhunyt Aszalay István kamarai ta- nácsos által a pozsonyi kollégiumra hagyott egykori Andreas Heindl-féle botanikus kertről is szólván) köszönetet mond az alapításért: PL AS, II. Acta Radicalia, Classis X, Nr. 196, 28. csomó, 411-412. Életrajzi adatait 1. Ladislaus Lukács: Catalogus generalis seu Nomenclator biographicus personarum Provinciae Austriae Societatis Iesu (1551-1773), III. Róma 1988, 1598.

39 PL AS, II. Acta Radicalia, Classis X, Nr. 196, 35. csomó, 288-290: 289: „der Jacob Maller ist vom Fürsten mit gnaden vnd seiner Satisfaction entlassen er wirrdt dem Fürsten ein andern maller Stöllen, ..."

40 PL AS, II. Acta Radicalia, Classis X, Nr. 196, 36. csomó, 238-340: 339: „Hr Küen hoffmahler Resigniert, geht $\mathrm{Cu}$ Summarum Wunderlich an dieses hoff, ..." Neuberger tartózkodásairól „az érsek udvarában” 1. Kemény Lajos: Adatok művészetünk történetéhez. Müvészet IV. 1905/5, 346-347: 347. Életrajzi adatainak öszszefoglalását bibliográfiával 1. Haupt 2007, 609 (Nr. 3090). Neubergernek az érsekkerttel kapcsolatos tevékenységét is ismertető tanulmányom előkészületben.

41 A további szövegrészek alapján bizonyos, hogy a levélben következetesen „úrként” („der herr”) aposztrofált személy nem lehet azonos sem a rendre "Herr Doctor"-ként megszólított Bonannusszal, sem a prímás címzéseiben szokványos „vnser Gnedigster fürst”, illetve „prinz” titulussal illetett Lippay érsekkel.

42 E lehetőség megemlítése alapján arra következtethetünk, hogy hasonló történhetett korábbi szerződése alkalmával is: februári elbocsátása, amely után ígéretet tett, hogy „egy másik festőt hoz" az érseknek, arra utalhat, hogy akkori munkáját szintén valamilyen hirtelen támadt nehézség miatt kényszerült megszakítani.

43 L.: 30-31. jegyzet.

44 A forrásokat l. a 33-34. jegyzetben. Ferdinand Khien besztercebányai születéséről Weszprémi is megemlékezik, de múvei címlapján és alkalmi költeményei szerzőjeként is így szerepel, wittenbergi disszertációját szintén "Novizolio-Hungarus"-ként jegyzi (RMK III/1. 2408).

45 Ragač 2005, 254; 1. 22. jegyzet. Az ifjabb Jacob Khien 1590-1595 körül születhetett. Talán ő a körmöcbányai városi levéltár 1624. évi pénztári naplójában említett „ifjú Khien festo"”, akit Bethlen Gábor Peter Hildebrandt asztalossal együtt Árva várába küld egy terem vizsgálatára és lerajzolására; 1. Križko Pál: Bethlen Gábor király Körmöczbányán. Századok XXXI. 1897, 593-606: 604-605, 1. jegyzet. (A főszövegben hibásan Josef Khien, a jegyzetben idézett forrásszövegben azonban „der Junge Khien Maller" szerepel. Az irodalomban az előbbi terjedt el; 1 . Garas 1953, 136.) A Khien família körmöcbányai kötődéséhez 1. Balážová 2007, 22, 24: 28., 29. jegyzet. - Az idősebb fiú: Johann Khien fia (a bécsi festő) szintén a Johann Christoph nevet kapta, róla 1. fentebb, ill. a 19-20. jegyzetben. Garas Klárának az itt foglaltaktól eltérő felvetését, miszerint a szobrász Johann Christoph Khien az ő fia volna, 1. Garas 2000, 343: 4. jegyzet.

46 Ecsedy 2013, 198.

47 A müről és tervezéséről 1. elsősorban: Ernyey 1912, 123-124., 126-127.

48 Bonnanus halálának időpontjáról és körülményeiről 1. Ernyey 1912, 126-127.

49 Philipp Jacob Sachs von Lewenhaimb: Ampelographia sive vitis viniferae ejusque partium consideratio physicophilologico-historico-medico-chymica... Lipcse 1661, I. 
43 - Az Academia Naturae Curiosorumról összefoglalóan 1. pl. Evans 1979, 373.

50 Philipp Jacob Sachs von Lewenhaimb: Observatio CXXXI. Aurum vegetabile. Miscellanea curiosa medicophysica Academiae Naturae Curiosorum... Annus primus anni scilicet M.DC.LXXmi... 1670, 290-293: 292 A mű további említései, ismertetései az itt megjelent adatokat ismételgetik, részben vagy összességükben; a teljesség igénye nélkül, a már említetteken túl l. Edward Brown: A Brief Account of some Travels in Hungaria, Servia, Bulgaria... London, 1673 (reprint: Karl Nehring Hrsg.: Veröffentlichungen des Finnisch-Ugrischen Seminars an der Universität München, Ser. C., Miscellanea 2. München, 1975), 95-96; Heinrich Christian Henninius: Jacobi Tollii Epistolae itinerariae: ex auctoris schedis postumis recensitae, suppletae, digestae; annotationibus, ... Amszterdam 1700, 123; Davidis Czvittingeri nob. Hung. Specimen Hungariae Literatae, virorum eruditione clarorum natione Hungarorum, Dalmatarum, Croatarum, Slavorum, atque Transylvanorum, vitas, scripta, elogia et censuras ordine alphabetico exhibens. Accedit Bibliotheca scriptorum qui extant de rebus Hungaricis. Frankfurt Lipcse 1711, 52; Bél Mátyás: Hungariae antiquae et novae prodromus... Nürnberg 1723, Praefatio, § VIII.; Weszprémi István: Succincta medicorum Hungariae et Transilvaniae biographia. Centvria prima / Kővári Aladár magyar fordításában: Magyarország és Erdély orvosainak életrajza. Első száz. I. kötet. (Lipcse 1774) Budapest 1960, 44-47; Horányi Elek: Memoria Hungarorum et Provincialium scriptis editis notorum. I-III. Viennae 1775-77, Pars II (1775), 183184: jegyzet; Georg v. Gyurikovits: Verlorenes Werk des Arztes Procopius Bonannus aus dem XVII. Jahrhundert, die Natur-Geschichte von Ungarn betreffend. Archiv für Geographie, Historie, Staats- und Kriegskunst XVI. 1825/73, 475 (kézirata: OSzK Kézirattár, Fol. Hung. 1256, ff. 101v-102.; magyar nyelvü kivonata a szerzőtől [1833]: Tudománytár X. 1836, 216, 15. sz.); Hanák János: Az állattan története és irodalma Magyarországon. Pest 1849, 17-18; Dr. Szathmáry László: Magyar alkémisták. Budapest 1928, 347; Kiss 2005, 445: 35. jegyzet; Papp Gábor: Az 1800 előtt ismert magyarországi drágakövek - Áttekintés. A Miskolci Egyetem Közleménye, A sorozat, Bányászat, 74. kötet. 2008, 157-224: 168.

51 Johann Paterson Hain: Observatio XXVIII. Morbi Hungariæ Endemii. Mineralia Hungariæ quædam. Miscellanea curiosa medico-physica Academiae Naturae Curiosorum... Annus secundus anni scilicet MDCLXXI... 1671, 55-59: 56.

52 Ernyey 1912, 125.

53 Bonannushoz szóló levelek: FK, Ms. I, 172 (Epistolae ad Procopium Polycarpum Bonanum, 1648-1662); PL AS, II. Acta Radicalia, Classis X, Nr. 196, főként a 35-36. csomó anyagában; Bonannus saját kezü, Lippay érsekhez írt levelei: PL AS, II. Acta Radicalia, Classis X, Nr. 196.

54 Nádasdy leveleit (FK, Ms. I, 172, 83-92. levél) és azoknak a De admirandis Hungariae rebus kiadására vonatkozó tartalmát említi: Ernyey 1912, 126; Kiss 2005, 445: 35. jegyzet. Az ábrákra vonatkozó (92. számú) levél megfelelő részletét (p. 170) idézi Ernyey 1912, 126: „Figurarum æriarum negotium ulteriori curæ \& conatui D. V[est] ræ commendamus." Nádasdy Ferenc nyomdáiról 1. Kiss 2005, 446; Viskolcz Noémi: Nádasdy III. Ferenc gyüjteményei. Századok CXLIV. 2010/4, 873-893: 887-888.
55 FK, Ms. I, 172, 92. levél, p. 170, idézi Ernyey 1912, 126: „De Typographya non est curandum, cum hic etiam ad idem Typographiæ munus obeundum tres vel quatuor [personas] ultro se offerentes habemus..."

56 Daniel Neuberger levelei Bonannushoz: PL AS, II. Acta Radicalia, Classis X, Nr. 196, 35. csomó, 288-314; 36. csomó, 338-371. A jáspisbánya ügyéről általánosságban 1. dr. Takáts Sándor: A jászpisz-kő feltalálása Magyarországon. Magyar gazdaságtörténelmi szemle IX. 1902, 139-140; ennek korrekciója: Ernyey 1912, 125: 1. jegyzet. A jáspisbánya használatáról 1659. július 18-án kelt szerződés Bonannus kézírásával lejegyzett tervezete (esetleg az irat kópiája), a Szentkereszt közelében lévő bánya helyének megjelölésével: Főkáptalani Levéltár, Esztergom, Főkáptalani Magánlevéltár, Ladula 49, Fasc. 6, Frusta 22, Nr. 16; ettől eltérő tervezet, Daniel Neuberger szerepének bemutatásával: uo., Fasc. 7, Frusta 23, Nr. 5. A Neubergerhez érkezett jáspiskövekről és azoknak a császári udvar megrendelésére való faragásáról szóló bécsi forrásokat (1661-1662) közli Herbert Haupt: Archivalien zur Kulturgeschichte des Wiener Hofes. III. Teil: Kaiser Leopold I.: Die Jahre 1661-1670. Jahrbuch der kunsthistorischen Sammlungen in Wien LXXIX (NF XLIII). 1987, 133ff.: Einleitung VI, Quellen-Nr. 1759, 1814, 1889, 1907, 1985.

57 PLAS, II. Acta Radicalia, Classis X, Nr. 196, 36. csomó, 359-363: 361: „,mir Ist noch vom H. Dr. nicht Ein Stainl Zu handen kommen, H. Kien Mahler (welcher hier gewesen) hab auch gefragt, weist niemanden nichts Orumb,..."

58 PL AS, II. Acta Radicalia, Classis X, Nr. 196, 35. csomó, 308-311: 310: „ferners hab Ich mit disem mahler geredt daß der hr: Ihne auff papir die gröste Stain nur gar schlecht von waßer farben mahlen laße, welche man heraußschikht oder Vorhanden seie, so können wir mit der Zeit wißen waß u Importanten stukhen gesandt würdt, Ich kan auch solhe visionung versänden vndt weÿsen, (Ich sage waß der müehe werth Ist ab zu zeichnen), ..."

59 Uo. 208: „durch H Liücx alß Kaisl: Chammer mahler hab Ich auch an Vndschiden orth schreiben Vndt bericht Einholen laßen, komht gutte antworth, ..." - Frans Luycx-ről 1. Ernst Ebenstein: Der Hofmaler Frans Luycx. Ein Beitrag zur Geschichte der Malerei am österreichischen Hofe. Jahrbuch der Kunsthistorischen Sammlungen in Wien XXVI. 1906, 183-254; Rózsa György: Frans Luyckx und György Szelepcsényi. Acta Historiae Artium VI. 1959/ 1-2, 233-238.

60 Uo. 310: „Vndt diß Ist u negotsien größter nutz zu beförderung, die Exemplaria so d hr: Kraff druckhen laßen, hatt Er auch alle beÿhanden, ..."

$61 \mathrm{Az}$ ásványok 17. századi szemléletének az „ars naturae" jegyében müvészeti konnotációiról, az ásványgyüjtés szempontjairól és a leletek természettudományos igényü ábrázolásának a fentiekkel összefüggő példáiról általában 1. Jurgis Baltrušaitis: Bilder im Stein. In: Uő: Imaginäre Realitäten. Fiktion und Illusion als produktive Kraft. (Aberrations. Les Perspectives Dépravées. Paris 1983.) Henning Ritter fordítása. Köln 1984, 55-89.

62 A jelenségről összefoglalóan 1. Evans 1979, 372-373.

63 A levelezésnek az érsekkertre vonatkozó részleteit, valamint Bonannusnak az érsekkert kialakításában játszott szerepét bemutató tanulmányom előkészületben.

64 Esterházy Pál mecénási tevékenységéről összefoglalóan 1. Galavics Géza: A mecénás Esterházy Pál (Vázlat egy pályaképhez). MÉ XXXVII. 1988/3-4, 136-161. 
65 MOL, P 125 (Esterházy Pál nádor), 28. csomó, 7197. sz. (Az irat kivonata az MTA BTK MI Regesztagyüjteményében: A-I-22, számozatlan regeszta, készítette: Badál Ede, 1979-1987.) A megállapodás szövege aláírás nélkül, Esterházy Pál kézírásával lejegyezve: „Anno 1664. die 23 Xbr. Alkuttunk meg Joannes Jakobus Khüen Képiroval, egy Kizler Laztlo névő Inasnak az Képirásnak mestersigire, mi számunkra két eztendő alat jol és az mi intentumunk szerént valo meg tanitássára, ugy hogy ez idő alat étellel itallal. és feÿer ruhaiának mosatassával tartza. Lészen azért fizetésse, az két eztendőben két száz forintya, mely két száz forintnak defalcatioiaban attunk neki mostan eötven forintot. Kiért eő is tartozik két eztendő mulva az föllől meg nevezet Kizler Laztlo mestersigiben fől szabaditani és Zaigniß levelet adni s minden vártorra magunknak is egy képet irni, s el is küldeni. Data Vienná die et Anno ut supra."

66 MOL, P 125 (Esterházy Pál nádor), 52. csomó, 11672. sz. (A jegyzék átiratai az MTA BTK MI Regesztagyüjteményében: A-I-22, 00786-00792: 00787, 00792. regeszta, készítette: Valkó Arisztid, 1950-1987.) A dátum és aláírás nélküli, „Az Bécsi képek Laistroma. Verzeichnuss der Mallereyen." címmel ellátott lista Esterházy Pál 1666-1669 között készült számadásai, számlái és végrendeletei között, az iratok eredeti sorrendje szerint található, tehát minden bizonnyal ekkor: a bécsi palota (I. Wallnerstrasse 4.) előzményét képező házak 1664-1669 között történt megvásárlása körüli időben, illetve kevéssel azt követően készült; 1. Richard Perger: Das Palais Esterházy in der Wallnerstrasse zu Wien. (Forschungen und Beiträge zur Wiener Stadtgeschichte Bd. 27.) Wien 1994, 20, 23, 24. A jegyzékről, Khün művét is említve 1 . Klára Garas: Die Geschichte der Gemäldegalerie Esterházy. In: Gerda Mraz - Géza Galavics Hrsg.: Von Bildern und anderen Schätzen. Die Sammlungen der Fürsten Esterházy. (Esterházy-Studien Bd. 2.) Wien - Köln - Weimar 1999, 101-174: 103; 1. továbbá: Galavics Géza: Jan Thomas, az utolsó Rubens-tanítvány és magyar mecénásai. MÉ LIV. 2005/1-2, 19-40: 37 (14. jegyzet).

67 Khün kismartoni munkáiról és ottani müködésének forrásairól 1. Csatkai-Frey 1932, XXXVIII, 58, 59; Garas 1953, 59, 136; Koppány 2011, 102.

68 MOL, P 125 (Esterházy Pál nádor), 48. csomó, 11128. sz. (Rövid kivonata az MTA BTK MI Regesztagyújteményében: A-I-22, 00709. regeszta, készítette: Valkó Arisztid, 1950-1987; hivatkozza: Garas 1953, 136; Koppány 2011, 102): „Heundt dato dem 22 appriell 1667 haben wür graf Palluß Esterhaßy mit Vnßern Mallern hanß Khienne auf 8 Zimmer $\mathrm{Zu}$ mahlen gedingt, welches er auf das allerfleigte Zuurichten soll, darueber Versprechen wir ihme fur solche arbeiht in Paren gelt Vierhundert gulten reich, wie auch die Kost mit den hantwerchßleithen sol deilen, Hirmit bezeigt Vnßer handtschrift vndt fertigung, Schloß Eißenstadt den 22 Appriel 1667 ..." Esterházy Pál aláírása után az összeg kifizetési részleteinek feljegyzése következik: Khün 1668. augusztus 16-án 100 forintot, október 15-én 50 forintot, december 27-én 100 forintot kapott kézhez; az összegek átvételét aláírásával igazolta. A fennmaradó 150 forint saját kezű átvételi elismervénye (évszám nélkül, feltehetően 1669-ből): MOL, P 125 (Esterházy Pál nádor), 48. csomó, 11022. sz.: „Denn 25 Jenner hab Ich In abschlag empfangen ain hundterd Reichstaller, so funfzig empfangen von dem herrn tienst Pottden welche in dem
Contrackht ab geschriben wordten bezeügd Mein handschriftd. Hanß Jacob Khien Mahler."

69 MOL, P 125 (Esterházy Pál nádor), 49. csomó, 11178. sz. (A Khün által aláírt szerződés szövegének részletét közli: Csatkai-Frey 1932, 58 (Nr. VIII); az iratot hivatkozza: Koppány 2011, 102.): „Heundt dato den 12. Jenner 1669. haben Wür Graff Paulluß Esterhäßÿ, Mit dem Hannß Jacob Khien, Maller von Prespurg, ordenlich gedingt, vnd beschloßen, daß Er Vnß in Vnßern Schloß Eißenstadt in dem Mitern stockh, das Zimer so mit rothem Märbel gepflastert, Item das Khleine öckch Zimber daneben, wie auch das Zimber an die Capellen, Item vnserer Frauen gräfin audienz vnd anthe stuben, Ingleichen ein Zimber, beÿ dem alten Vieregten Thurm, vnd dan in dem obern stockch, ober dißeß bemalten Zimer, Zwä̈ öckch Zimer Zusamben acht Zimer mit aller gebihrlichen, vnd feinesten, auffrichtig schönen Mallereÿ verßehen, vnd Verfertigen solle. Von welche arbeith Wür Ihme Vierhundert gulten reimb. Zug eben versproch, ..."

70 A helyiségek azonosításának kísérlete az Esterházy Pál idején kialakult s a 18. század közepéig fennálló elrendezés Stefan Körner és Margit Kopp által közölt alaprajzi rekonstrukcióján, továbbá a két szerzőnek a termek funkcióját, a berendezés részét képező festményeket és az ezek alkotta tematikus ill. programatikus egységeket bemutató tanulmányán alapul; 1. Körner-Kopp 2010, 232236, Abb. 21a, b.

71 Körner-Kopp 2010, 233: Abb. 21a (Nr. 23-25), 234. (Az itt elhelyezett festmények között Esterházy-ősök egészalakos portréi mellett táj- és csataképek, zsánerjelenetek, vallásos tárgyú képek és hónapképek is voltak.)

72 Körner-Kopp 2010, 233: Abb. 21a (Nr. 32-33), 234. (Családi portrékkal, valamint Dianát és Juditot ábrázoló festményekkel.) Az „előszoba” megnevezést talán az magyarázza, hogy a toronyban lévő szobával azonosított audienciás (belső) szobához (uo. Nr. 32) észak felől csatlakozó helyiség (uo. Nr. 33) méretére és helyzetére, valamint a felsőbbrendű helyiséghez való kapcsolódásának módjára nézve szinte pontosan a nagyterem keleti sarkához dél felől csatlakozó s a (kevéssel későbbi) forrásokban „Vorzimmerként” szereplő kisebb terem (uo. Nr. 13) megfelelője volt.

73 Körner-Kopp 2010, 233: Abb. 21a (Nr. 17-19), Abb. 21b (Nr. 2-5), 234, 235; 72. jegyzet. (A torony a "réginek", „rossznak" tekintett bútorok és képek gyưjtőhelyévé vált, s családtagok arcképei mellett a Nádasdy-család néhány tagjának potréit, pogány királyok arcképeit, ivó és dohányzó alakokat megjelenítő zsánerképeket helyeztek el benne.)

74 A kastély néhány terme, így a nagyterem melletti helyiség 17. századi falképeinek újabban feltárt részleteiről készült fotók ismeretét Galavics Gézának köszönöm.

75 MOL, P 125 (Esterházy Pál nádor), 12. csomó, 2876. sz. (Kivonata és részleges átirata az MTA BTK MI Regesztagyüjteményében: A-I-22, számozatlan regeszta, készítette: Badál Ede, 1979-1987.) A levél részlete: „... Emellet őrömel tudnam az arant az Ngok szandekat, ha az nalunk levö Capolnaban á mellyet Nagok ara vetetet, ha az temetö helt Nagok sub sua iurisdictione folttyaie á uagi masokknak adhattyuk, (mivel Nagokk uan temetö helek Szombadban) ualamint Nagok akaria, nekem mind kedues lesen. A posoni KepIro ada ertesemre, hogy Nagtok á megh neuezet Capolnaban nalunk leendö Oltar 
veget szollot legyen uele; kerem alazatossan Nagokat ha foglalatossagi miat egy szer ideie lesen, adna kézeben az oltarnak mintaiat, hogy lassan lasan azis keszülhetne el: á melly Nagok sok rendbéli uelünk tet io cseleketeit mindennapi Sz: Misseinkben megh igyekesünk halalni es szolgalni ..." - A levélíró: Kovách Ambrus 1648-1651 között a rend provinciálisa volt; 1. Dr. Karácsony Sándor: Szt. Ferencz rendjének története Magyarországon 1711-ig, I-II. Budapest 1922, I. 118, 120, 301. 1654-ben a nagyszombati, majd 1657-ben és 1660-ban a győri konvent gvardiánjaként ír Lippay érseknek (előbbi minőségében többek között a nagyszombati klarisszák épületének javításáról); leveleit 1. PL AS, II. Acta Radicalia, Classis X, Nr. 196, 20. csomó, 473-474, 21. csomó, 80-81, 29. csomó, 341-342.

76 Buzási 2000, 333 és Buzási 2005, 279: 96. jegyzet nyomán: Kirkay 1715-1783, 4: „Illustrissimus Comes Paulus Esterhazy, verè Parens Provinciae curat unum Altare pro prima Capella Ecclesiæ, qvae nunc est Sacry Rosarÿ flor. 200." - A győri ferencesek templomának Esterházy Pál által adományozott oltáráról és annak egy vagy több oltárképéről igen keveset tudunk. Az egyetlen forrásunk valójában a konvent Kirkay Lajos által jegyzett, fent idézett protokollumának megfelelő részlete. A templom „első kápolnájának" Esterházy Pál által adományozott oltára eszerint a protokollum készítésének idején a Rózsafüzértársulat használatában volt. (A győri Congregatio Sancti Rosariit 1625-ben a bécsi dominikánusok alapították meg a győri Szent Ignác jezsuita [később bencés] templomban, a ferences konvent kérésére; 1. Piszker Olivér: Barokk világ Győregyházmegyében Zichy Ferenc gróf püspöksége idején [1743-83.] [Pannonhalmi füzetek, 13.] Pannonhalma 1933 , 23.) A társulat kápolnájában a 18. században a Fájdalmas Szűz oltára állt. Ennek első datált említése az 1722. évi templomfelújítási munkák leírásánál szerepel a protokollumban (Kirkay 1715-1783, 13: „19 Aug oblata sunt duo Candelabra cum tabulis 3bus pro Altari B. V. Dolorosæ"). 1748-ban a Hueber család jóvoltából, úgy tünik, új oltár került a korábbi helyére. (L. Kirkay 1715-1783, 19: „Erectum est Altare novum B. V. Dolorosæ ex munificentia [...] Hueberianæ.") Az oltárt 1795-ben renoválták. (L. Kirkay 1715-1783, 30: „1775. Aram [...] S. Francisci, aram B. V. M. Congregationis SS. Rosarÿ curarunt renovati.") Az oltár korábbi (datált) említésével nem találkozunk a protokollumban. Az oltárról Kirkay megemlékezik munkájának a templom "dedikációit": kriptáit és oltárait bemutató fejezetében is: a főoltár melletti (második) kriptánál (tehát a templom első kápolnájában) leírása szerint egy bizonyos „Altare Beatæ Virginis Hokburgiana" állt (Kirkay 1715-1783, 72; említi: Buzási 2005, 279: 99. jegyzet). Amennyiben nem tévedésről van szó, ez az említés nem Esterházy Pál, hanem a nemességet kapott és a csókakői uradalmat 1691-ben megszerző Hochburg János, a győri várőrség élelmezési főtisztje (férfiágon 1752-ben kihalt) családjának adományozói szerepére utal (1. Ignaz Seidel: Chronologische Erzählung der Ereignisse und Begebenheiten in der Herrschaft Csókakö-Móor im Stuhlweissenburger Comitat in Ungarn. Steyr 1898, 4-9). Kirkay leírása azonban nem a 17. századi, hanem a 18. századi állapotot rögzíti (ennek ellenére az oltárok 17. századi rendjére vonatkoztatja: Németh Ambrus: Adalékok a szentferencrendiek egykori győri kolostorának történetéhez. Győri Szemle II. 1931, 96-104: 101). Úgy tünik tehát, hogy - bár a kápolna ti- tulusát illetően feltehetően nem esett változás - az Esterházy Pál által adományozott oltár helyére valamiképp a Hochburg családhoz kapcsolódó Mária-oltár került, vélhetően már a 18 . században. Talán a 18 . század első felében tett oltáradományról van szó (bár a protokollum ilyet nem említ), de talán nem elképzelhetetlen, hogy esetleg a Rózsafüzér-kongregáció kápolnahasználatával összefüggésben - másodlagos elhelyezésben került ide egy eredeti helyén a Hochburg család valamely tagja által adományozott oltár, ahogy az is lehetségesnek tünik, hogy a Kirkay-féle protokollum csupán a székesegyház azonos titulusú Mária-oltárára: esetleg az oltárkép hasonló típusára utal a „Hokburgiana” jelző használatával. A famíliának ugyanis egyetlen győri oltáradományát ismerjük: Az 1676-ban meghalt Hochburg János és felesége emeltette a győri székesegyház déli mellékhajójának második, egykori Fájdalmas Szűz-oltárát, amelynek helyére 1772-1774-ben Joseph Gottschall bécsújhelyi kőfaragó, valamint Franz Anton Maulbertsch és mühelye közreműködésével új oltárt állítottak; 1. Bedy Vince: A győri székesegyház története. (Győregyházmegye multjából, I. szám.) Győr 1936, 19 (10. sz.), 25, 26, 125; a Maulbertsch-mühely által kivitelezett új oltárképről 1. Garas Klára: Ismeretlen Maulbertsch-oltárképek Magyarországon. MÉ VI. 1957, 119-127: 122, 127; Klára Garas: Franz Anton Maulbertsch, 1724-1796. Budapest 1960, Dokument LIV, Wekverzeichnis 279; Géza Galavics: Die Identifizierung einer Budapester Maulbertsch-Skizze mit Bemerkungen zum Schaffensprozess bei Maulbertsch. Vorlage, Entwurf, Kopie, Paraphrase. Acta Historiae Artium L. 2009, 119-146: 129, 133, 135, Abb. 10-11. Az eredeti, Esterházy által adományozott oltár és tartozékai sorsa tehát ismeretlen; a fentiek alapján kézenfekvőnek tünik a feltételezés, hogy a 18. században eltávolították őket a templomból, és esetleg a kolostorban kaptak helyet. Egy vagy több oltárképének, úgy tünik, nincs nyoma. Buzási Enikő két nagyméretü, meglátása szerint a győri ferencesek javaiból származtatható festményt (olaj, vászon, $110 \times 198 \mathrm{~cm}$ ) kapcsolt Esterházy Pál mecenatúrájához: egy Szent Erzsébetet és egy koldust, továbbá egy Szent Imrét megjelenítő, a győri püspöki palotából származó egykori oltárképet (MNG RMGy, ltsz. 81.8 és 81.7), utalva azoknak a fraknói ősgaléria több darabjával: Esterházy Pál egyik udvari festőjének műveivel, közülük is elsősorban „Eszterhás Christina Benedictina apácza” egészalakos fiktív portréjával való „,feltünő egyezésekre”, amelyek különösen az arcok kivitelében nyilvánvalóak. Mivel az egymás párdarabjaként elképzelt két festmény közül a Szent Imre-oltárkép nyoma nem fellelhető sem a feloszlatási jegyzőkönyvben, sem a templom mellékoltárairól tudósító korábbi forrásokban, Buzási Enikő a képeket nem a templomból, hanem a kolostorból származtatta, amelynek festményeiről a feloszlatási jegyzőkönyvben csupán mennyiségi, méretbeli, illetve a becsértékükre vonatkozó adatok találhatók, és feltételezi, hogy a képek eredetileg is a kolostor számára készültek, annak 1673-ban befejezett újjáépítését követően, 1675-1680 körül. L. Buzási 2000, 332-333.

77 A jelenségről összefoglalóan és részleteiben 1 . Buzási Enikő: Portrék, festők, mecénások. A portré történetéhez a 16-17. századi Magyar Királyságban. In: Mikó Árpád - Verő Mária szerk.: Mátyás király öröksége. Késő reneszánsz müvészet Magyarországon (16-17. század). 
II. kötet. Tanulmányok. (A Magyar Nemzeti Galéria kiadványai 2008/4.) Budapest 2008, 25-53: 25-26. A pozsonyi "helyzetkép" és a tágabb korszak név szerint ismert pozsonyi festőinek ismertetését 1 . uo. 25-26, 45: 8. jegyzet.

\section{RÖVIDÍTVE IDÉZETT IRODALOM}

Balážová 2007 - Barbara Balážová: „Ein großes auf Holz gemaltes Bild der Geburt Christi für ungefähr $10 \mathrm{Gul}-$ den". In: Uő Hrsg.: Generationen, Interpretationen, Konfrontationen. Sammelband von Beiträgen aus der internationalen Konferenz in den Tagen 20-22. April 2005 in Bratislava. Bratislava (Ústav dejín Slovenskej akadémie vied - Institut für Kunstgeschichte der Slowakischen Akademie der Wissenschaften) 2007, 17-25.

Balážová 2009 - Barbara Balážová: Stredoslovenské banské mestá po roku 1526 - príbeh umenia renesancie alebo reformácie? In: Rusina 2009, 49-60.

Bubryák 2003 - Bubryák Orsolya: Egy polgári mecénás a 17. században. Weber János eperjesi főbíró (1612-1684). Ars Hungarica XXXI. 2003/2, 225-280.

Buzási 2000 - Buzási Enikő in: Mikó Árpád - Sinkó Katalin szerk.: Történelem - kép. Szemelvények múlt és művészet kapcsolatából Magyarországon. Kiállítás a Magyar Nemzeti Galériában 2000. március 17 - szeptember 24. (A Magyar Nemzeti Galéria kiadványai 2000/3.) Budapest 2000, 332-333, kat. sz. V-24 .

Buzási 2005 - Buzási Enikő: A Köpenyes Madonna Árpásról. Jan Thomas Nádasdy Ferenc számára festett müve 1663-ból. (Meghatározás, datálás, attribúció.) MÉ LIV. 2005/3-4, 245-286.

Csatkai-Frey 1932 - André Csatkai - Dagobert Frey: Die Denkmale des politischen Bezirkes Eisenstadt und der freien Städte Eisenstadt und Rust. Österreichische Kunsttopographie XXIV. Wien 1932.

Ecsedy 2013 - Ecsedy Anna: Plenus sapientia: Lippay György esztergomi érsek pozsonyi kertjének látványosságai. Müvészettörténeti Értesítő LXII. 2013/2, 171-232.

Ernyey 1912 - Ernyey József: Természettudományi mozgalmaink a 17-18. században. Természettudományi közlöny XLIV. 1912/3-4. pótfüzet, 113-129.

Evans 1979 - Robert J[ohn] W[eston] Evans: The Making of the Habsburg Monarchy. Oxford 1979.

FK - Főszékesegyházi Könyvtár, Esztergom.

Garas 1953 - Garas Klára: Magyarországi festészet a XVII. században. Budapest 1953.

Garas 2000 - Garas Klára: Schlachtenbilder und fremde Maler in Venedig. Ferdinando Chieni pittore Ungaro. In: Alenka Klemenc ed.: Vita artis perennis. $\mathrm{Ob}$ osemdesetletnici akademika Emilijana Cevca. Ljubljana 2000, 341-356.

Hajdecki 1908 - Alexander Hajdecki: Auszüge aus den Ehematriken von St. Stephan. In: Albert Starzer Hrsg.: Quellen zur Geschichte der Stadt Wien, I. Abteilung: Regesten aus in- und auslandischen Archiven, VI. Wien 1908, 53-113.

Haupt 2007 - Herbert Haupt: Das Hof- und hofbefreite Handwerk im barocken Wien 1620 bis 1770. (Forschungen und Beiträge zur wiener Stadtgeschichte, 46.) Innsbruck - Wien - Bozen 2007.

Kirkay 1715-1783 - Prothocolum Venerabilis Conventus Iaurinensis. [...] in quo continentur omnia acta memorabilia et notatu digna tam superioribus, quam cu- riosis lectoribus [...] conscriptore patre fratre Ludovico Kirkaÿ, Conventus huius Urbilis Immerito Gvardiano, [...] Anno Domini 1715. Continuatio usque ad annum 1783. Országos Széchényi Könyvtár, Budapest, Kézirattár, Fol. Lat. 4141.

Kiss 2005 - Kiss Farkas Gábor: "Difficiles Nugae”: Athanasius Kircher magyarországi kapcsolatai. Irodalomtörténeti Közlemények CIX. 2005/4-6, 436-468.

Koppány 2011 - Koppány Tibor: Az Esterházy-család fraknói ágának múvészei és mesterei a 17. században. Ars Hungarica XXXVII. 2011/4, 93-109.

Körner - Kopp 2010 - Stefan Körner - Margit Kopp: Die Bilderwelten des Fürsten Paul Esterházy. Gemälde und Bildprogramme. In: Bubryák Orsolya szerk.: „Ez világ mint egy kert..." Tanulmányok Galavics Géza tiszteletére. Budapest 2010, 215-248.

MÉ - Müvészettörténeti Értesítő.

Mikó - Verő 2008 - Mikó Árpád - Verő Mária szerk.: Mátyás király öröksége. Késő reneszánsz müvészet Magyarországon (16-17. század). Kiállítás a Magyar Nemzeti Galériában 2008. március 28 - 2008. július 27. [I. kötet. Katalógus.] (A Magyar Nemzeti Galéria kiadványai 2008/3.) Budapest 2008.

MNG RMGy - Magyar Nemzeti Galéria, Budapest, Régi Magyar Gyüjtemény.

MOL - Magyar Nemzeti Levéltár Országos Levéltára, Budapest.

MTA - Magyar Tudományos Akadémia, Budapest.

MTA BTK MI, Regesztagyüjtemény - MTA Bölcsészettudományi Kutatóközpont, Művészettörténeti Intézet, Levéltári Regesztagyűjtemény.

PL AS - Prímási Levéltár, Esztergom, Archivum Saeculare Ragač 2005 - Radoslav Ragač: Maliar Jakub Khien starší $\mathrm{v}$ písomných prameňoch banskobystrickej proveniencie. (Der Maler Jakub Khien der Ältere in Schriftquellen mit Provenienz aus Banská Bystrica / Painter Jakub Khien Senior in the Written Sources of the Banská Bystrica Provenance.) Monumentorum tutela XVI. 2005, 247-256.

Rapaics 1938 - Rapaics Raymund: A pozsonyi kert. Természettudományi közlöny LXX. 1938. 1089. sz., 664-675.

Rusina 2009 - Ivan Rusina et al.: Renesancia umenie medzi neskorou gotikou a barokom. Dejiny slovenského výtvarného umenia. Bratislava (Slovenská Národná Galéria) 2009.

Štibrányiová 1987 - Mária Štibrányiová: Trnavskí majstri murári, kamenári, sochári, maliari a štukatéri 17. storočia. In: Umenovedný ústav Slovenskej Akadémie Vied. Problémy umenia 16.-18. storočia (zborník referátov zo sympózia). Bratislava 1987, 79-91.

Weszprémi 1781 - Weszprémi Istuán: Succincta medicorum Hungariae et Transilvaniae biographia. Centuria altera, Pars posterior. Wien 1781.

Weszprémi / Kövári (1781) 1968 - Weszprémi István: Succincta medicorum Hungariae et Transilvaniae biographia. Centuria altera / Kövári Aladár magyar fordításában: Magyarország és Erdély orvosainak életrajza. Második száz. II/2. kötet. (Wien 1781) Budapest 1968. 


\section{DATA TO THE WORK OF JOHANN JACOB KHÜN, "PAINTER TO THE ARCHBISHOP”, AND THE NEWLY FOUND EASTERN VIEW (1663) OF GYÖRGY LIPPAY'S SUMMER RESIDENCE IN POZSONY}

Archbishop of Esztergom György Lippay's (1600-1666) summer residence and garden in Pozsony were represented on a series of engravings published in 1663. A hitherto unknown piece of this series features the eastern view of the residence (Bibliotheca Ecclesiae Metropolitanae Strigoniensis, Esztergom; fig.). The sheet bears the signature of Johann Jacob Khün, painter to the archbishop who supposedly produced the drawings for the entire series.

According to various sources most of which were concluded by Klára Garas, Khün came from a family of over four generations of painters and sculptors originated in Besztercebánya. The present study attempts to uncover documents representing Khün's family relations and personal connections in the milieu of the archbishop's court at Pressburg.

Only a few sources remain on Johann Jacob Khün's work in archbishop Lippay's service. Based on a few miscellaneous allusions and the painter's recently recovered letter written to the archbishop's physician and familiar Polycarpus Procopius Bonannus (d. 1664) in 1659, the author presumes that Khün was the grandson of Jacob Khien the elder (d. after 1619) who created the so-called Zmeskál epitaph (Berzevice, c. 1600). Johann Jacob Khün's father was probably the painter Jacob Khien the younger who became a burgess of Besztercebánya in 1619. Pozsony sculptor Johann Christoph Khien (d. 1696/97), creator of the Holy Trinity column of Nagyszombat (1683-1695), and Ferdinand Khien, a doctor born in Besztercebánya who graduated at the University of Wittenberg (1667) and later worked in Eperjes and Pozsony were probably Johann Jacob Khün's brothers. Judging by the 1659 letter and other sources, Khün's brother Ferdinand may well have been helped with the starting of his medical career by Bonannus who probably interceeded for him to spend his pharmacist's training in Johann Weber's (1612-1684) pharmacy in Eperjes.

Khün's letter implies that he may well have produced illustrations for Bonannus's ambitious but ultimately unpublished and lost opus describing Hungary's geographical and mineralogical treasures, entitled De admirandis Hungariae rebus, backed by archbishop Lippay and Lord Chief Justice Ferenc Nádasdy (1623-1671). The correspondence of Bonannus, a rare group of sources, provides some important data to the project and Khün's surmized participation, and might as well lead to closer acquaintance with the process of furnishing and decorating of archbishop György Lippay's summer residence and garden of Pozsony.

A year after the publishing of the print series Khün already worked as a court painter to Count (later Palatine and Prince) Pál Esterházy (1635-1713). Between 1664 and 1671 he produced at least eight paintings for him, and decorated sixteen rooms of his Kismarton Castle.

ECSEDY Anna művészettörténész / art historian, Budapest, anna.ecsedy@gmail.com

Kulcsszavak: 17. század, kert, kastély, rézmetszet, Pozsony, Eperjes, Besztercebánya, Esztergom, Főszékesegyházi Könyvtár, Kismarton (Eisenstadt), Győr, Lippay György esztergomi érsek, Nádasdy Ferenc országbíró, Esterházy Pál, Johann Jacob Khün (Hans Jacob Khien), Polycarpus Procopius Bonannus, Daniel Neuberger / Keywords: 17th century, garden, house, engraving, Pozsony, Eperjes, Besztercebánya, Esztergom, Bibliotheca Ecclesiae Metropolitanae Strigoniensis, Kismarton (Eisenstadt), Győr, Archbishop György Lippay, Lord Chief Justice Ferenc Nádasdy, Pál Esterházy, Johann Jacob Khün (Hans Jacob Khien), Polycarpus Procopius Bonannus, Daniel Neuberger 